\title{
Göstergebilimsel Çözümlemelerle Realist Sanat Eserlerinin Sosyolojik Anlatıları Üzerine İncelemeler
}

\author{
Examinations on Sociological Narratives of Realist Works of Art with Semiotic \\ Analysis
}

Uğur YILMAZ ${ }^{1}$

\author{
Araștırma Makalesi / Research Article \\ Geliș Tarihi / Received: 06.09.2021 \\ Kabul Tarihi / Accepted: 10.11.2021 \\ Doi: 10.48146/odusobiad.991774
}

Atıf / Citation: Yılmaz, U. (2021). "Göstergebilimsel Çözümlemelerle Realist Sanat Eserlerinin Sosyolojik Anlatıları Üzerine İncelemeler”, ODÜSOBİAD, 11(3), 837-852 Doi: 10.48146/odusobiad.991774

\begin{abstract}
Öz
$\mathrm{Bu}$ araștırmanın amacı, realist sanat eserlerindeki görsel anlatıların toplumsal olay ve olgularla ilișkilerini göstergebilimsel olarak incelemektir. Sanat eleştirisi incelemesi özelliği gösteren bu araştırmada realizm sanat akımının önde gelen temsilcileri arasında yer alan Gustave Courbet, Jean-François Millet ve Adolph Von Menzel'in eserleri üzerine odaklanılmıștır. Bu kapsamda araştırmada Gustave Courbet'nin Taş Kırıcılar, JeanFrançois Millet'nin Hasatçılar ve Adolph Von Menzel'in Demir Haddehanesi adlı eserleri incelemeye alınmış, söz konusu eserlerin görsel anlam katmanlarında yer alan iletilerin sosyolojik anlatılarla ilișkileri değerlendirilmeye çalışılmıştır. Araştırmaya konu olan eserlerin görsel anlam katmanlarını inceleyebilmek için göstergebilimsel çözümlemeden yararlanılmıştır. Araştırmada göstergebilim anlam çözümleme çalışmaları betimsel, anlatımsal ve izleksel düzeylerde gerçekleştirilmiştir. Göstergebilimsel çözümlemeler sonucunda, resimlerin üretildikleri dönemin toplumsal olay ve olgularına yönelik derin anlam iletileri içerdikleri görülmüștür. Resimlerin görsel anlam katmanlarında yer alan ve yorumlamaya konu olan başlıca sosyolojik söylemler arasında; toplumsal sınıf tabakaları (alt ve üst sınıf), toplum tipleri (tarım ve yeni sanayileşmekte olan toplumlar), sosyalizm, sanayi (endüstri) devrimi, inanç sistemi, işçi sınıfı (proletarya) vb. iletilerle karşılaşılmıştır. Realist sanatçıların yansıtmacı (mimesis) prensiplerinin, sadece formların görüntüsel gerçekliğini tasvir etme yönünde değil aynı zamanda toplumsal olay ve olguların dünyevi karşılıklarını en açık şekilde işleme konusunda da belirginlik gösteren bir tasvir anlayışı özeliğine sahip olduğu görülmüştür. Bu özelliğin, realist anlatımın eleştirel nitelikli sosyolojik bir özelik kazanması noktasında önemli rollere sahip olduğu anlaşılmıştır. Realist sanat eserlerinin enformel eserlere göre öznel yorumlara daha kapalı bir özellik göstermesinin, söz konusu eserlerin görsel iletilerinden sosyoloji ve tarih araştırmalarında bir tür tarihsel belge ve görsel veri olarak yararlanılabileceği konusunu karşımıza çıkarmıştır.
\end{abstract}

Anahtar Kelimeler: Realizm, Göstergebilimsel Çözümleme, Sanat Sosyolojisi, Sanat Eleștirisi, Resim

\begin{abstract}
This research aims to examine the relationship of visual narratives in realist works of art with social events and phenomena semiologically. In this research, which has the feature of art criticism, it was focused on Gustave Courbet, Jean-François Millet, and Adolph Von Menzel, who are among the leading representatives of the art movement of realism. In this context, the work of Gustave Courbet's The Stonebreakers, Jean-François Millet's The Gleaners, and Adolph Von Menzel's The Iron Rolling Mill were examined in the study, and the relationship between the messages in the visual meaning layers of these works and sociological narratives was tried to be evaluated. Semiotic analysis was used to examine the visual meaning layers of the works subject to the research. In the study, semiotics analysis studies were carried out at the levels of descriptive, narrative, and deep structure. As a result of semiotic analyzes, it was seen that the paintings contained deep meaning messages about the social events and phenomena of the period in which they were produced. Among the main sociological discourses in the visual meaning layers of the paintings and subject to interpretation; social class strata (lower and upper class), types of society (agriculture and newly industrialized societies), socialism, the industrial revolution, belief system, workingclass (proletariat), etc. were encountered. It has been observed that the reflective (mimesis) principles of realist artists have a clear sense of depiction not only in terms of depicting the visual reality of forms but also in terms of
\end{abstract}

\footnotetext{
${ }^{1}$ Arş. Gör. Dr., Aksaray Üniversitesi, Eğitim Fakültesi, Güzel Sanatlar Eğitimi Bölümü, Resim-İş Eğitimi Anabilim Dalı, Aksaray, e-mail: uyilmaz.rssm@gmail.com, ORCID ID: 0000-0003-0435-5012
} 
processing the worldly equivalents of social events and phenomena most explicitly. It has been understood that this feature has an important role in terms of realist expression gaining a critical sociological feature. The fact that realist works of art are more closed to subjective interpretations than informal works has shown us the issue that the visual messages of these said works can be used as a kind of historical document and visual data in sociology and history research.

Keywords: Realism, Semiotic Analysis, Sociology of Art, Art Criticism, Painting

\section{Giriș}

Realizm (gerçekçilik), süjenin dış dünyaya iliş̧in duyumlarını nesnel bir yaklaşım içerisinde taklit/tasvir etmesi anlamında sanatsal bir anlayışı ifade etmektedir. Bu tanım çerçevesinde realizm her ne kadar natüralist bir anlayışın varlığını çağrıştırıyor olsa da Thompson'un (2014) belirtiği gibi realizmi natüralizmin karşıtı olarak değerlendirmek gerekmektedir. Konuyla ilgili olarak Krausse (2005) çalışmasında Gustave Courbet'nin ifadesi üzerinden realizmi, idealin reddine dayanan; öz itibariyle demokratik bir sanat anlayışı olarak ifade etmiştir. Klasik ve romantik sanatçıların formları idealist bir anlayışla resmetme eğilimlerinden ayrışan realist sanatçıların tutumlarının, 19. yüzyıl ortalarında günlük yaşamın sıradanlığını, toplumsal olgu ve düşüncelerini tüm açıklığıyla resmetme yönünde bir özellik gösterdiği görülmektedir (Antmen, 2013, s. 12). Realist sanatçıların bu tutumuna yönelik Hauser (2006) çalışmasında, realizmde günlük yaşamın tüm açılığı ve kabalığıyla resmedilmesinin sanat tarihinde bir yenilik olmadığına; fakat toplumun yapay bir kurguya dönüștürülmeden ele alınmasının ve bu durumun sonucu olarak sanatın kazanmış olduğu siyasal tutumun bir yenilik olarak değerlendirilmesi gerektiğine dikkat çekmiştir. Tüm bu konularla ilgili olarak realizmin, Rönesans'tan 19. yüzyılın ortalarına kadar sanat tarihinde doğayı idealist bir anlayışla taklit etme/betimleme yönündeki sanatsal eğilimlerden uzaklaşarak dönemin toplumsal koşullarının etkileriyle -bunlar arasında en belirleyici olanı sanayi devrimidir- modern sanat felsefesinin temellerinin șekillenmesine kaynaklık yapığı ifade edilebilir.

Realist sanatçıların formalist (biçimci) bir anlayışla kurguladıkları resimlerinin arka yapısında işledikleri konularla sanatı sosyolojik bir anlatı aracına dönüștürdükleri; dönemin düşünce iklimi, toplumsal tahakküm biçimleri ve modern sanatın eleştirel işlevi üzerine avangart bir sanatsal anlayışın kapılarını açtıkları düşünülmektedir. $\mathrm{Bu}$ anlayışla ilişkili olarak bazı sanat tarihi incelemelerinde realizmin modern sanatın başlangıcını belirleyen bir sınır çizgisi olarak değerlendirildiği görülmektedir (Arnason \& Mansfield, 2013; Krausse, 2005; Mallarmé, 1982; Malpas,1997; Thompson, 2014). Yine, realizmin öncü sanatçısı Courbet'nin resimlerinin toplumsal ve sanatsal ilerlemenin etimolojik kökenleri anlamında avangart bir özellik gösterdiği ifade edilir (Nochlin, 1989, s. 12). Realizmin Rönesans'tan beri sanat tarihinde var olan diğer formalist yaklaşımlardan ayrılan en önemli özelliği, toplumsal yapının bileşenlerine yönelik eleştirel nitelikli sosyolojik anlatımlar içeren konular üzerine odaklanıyor olmasıdır. Bu durum üzerinde realist sanatçların dönemin toplumsal olay ve olgularına yönelik üstlendikleri muhalif tutumların belirleyici olduğu düşünülmektedir. Bu kapsamda, Courbet'nin resimlerinin 1855 yllında Paris'te organize edilen Universal Exhibition'a (Dünya Fuarı) kabul edilmemesinin ardından 'Le Réalisme' (Realizm/Gerçekçilik) başlığı altında sanatçının kendi olanaklarıyla resimlerini sergileme girişimi (Honour \& Fleming, 2016; The Metropolitan Museum of Art, 2008); yine, Paris'te Salon'a yapilan başvurular sonrasında reddedilen realist ve empresyonist sanatçıların 'Reddedilenler Salonu' adı altında resimlerini sergilemeleri (Antmen, 2013, s. 20); Sanayi Devrimi'nin meydana getirdiği endüstrileşme olgusuna paralel olarak buharlı makinelerin yaygınlaşması, mekanik üretim sistemlerinin insan emeği ve iş gücü üzerinde doğurduğu etkiler vb. olaylar realist sanatçıların sanatsal anlayışlarını şekillendiren temel toplumsal faktörler olarak karşımıza çıkmaktadır.

Realist sanatçıların dıș dünyayı tüm açıklığıyla resmetme yönündeki eğilimleri, realizmin toplumsal olay ve olgularla ilişkilerini belirginleştirmeye yardımcı görüntüsel göstergeler elde etmeyi ve realist sanat eserleri üzerinden gerçekleştirilebilecek sanat sosyolojik değerlendirmeleri mümkün kılan bir özellik olarak karşımıza çıkmaktadır. Sanat ve toplum etkileşimini çözümleme konusunda realist sanat eserlerinin izleyiciye, döneminin sosyal, kültürel, tarihsel ve bilimsel gelişmelerine yönelik olarak günlük yaşam tasvirleri sunduğu görülmektedir. Bu durum üzerinde realist sanatçlların imgeleri manipülasyona uğratmandan tasvir etme eğilimlerinin önemli rolleri bulunmaktadır. $\mathrm{Bu}$ anlamda realist sanatın ideolojisini, fotoğrafik gerçekliğin sahip olduğu nesnellik ve sıradanlık ilkeleriyle ilişkilendirilebileceği düşünülmektedir. Fotoğraf imgeleri üzerinden toplumsal içerikli veri elde etme konusunda karşımıza çıkan görsel sosyoloji çalışmalarıyla (Cipriani \& Del Re, 2012; 
Boucher \& Watson, 2017; Harper, 2012; Pauwels, 2010; Power, 2003; Wagner, 2002; Williams \& Whitehouse, 2015) ilişkili olarak bu araştırmada, realist sanat eserleri üzerinden toplumsal içerikli veri elde etmeye odaklanılmıştır. Bu noktada sanat sosyolojisi ve görsel sosyoloji ışı̆̆ında göstergebilim anlam çözümleme çalışmalarıyla realist sanat eserleri üzerinden toplumsal içerikli veriler elde edilebileceği; realist sanat eserlerinde işlenen toplumsal anlatımlardaki alt anlam katmanlarının ortaya çıkarılabileceği düşünülmektedir. Tüm bu konularla ilgili olarak araştırmada, realizm akımının özellikleri çerçevesinde realist sanat eserlerinin görsel anlam katmanlarında yer alan sosyolojik anlatıların ortaya çıkarılması hedeflenmiștir.

\section{Araştırmanın Amacı}

$\mathrm{Bu}$ araştırmanın amacı, realist sanat eserlerindeki görsel anlatıların toplumsal olay ve olgularla ilişkilerini göstergebilimsel olarak incelemektir. Sanat eleștirisi incelemese özelliği gösteren bu araștırmada realizm sanat akımının önde gelen temsilcileri arasında yer alan Gustave Courbet, JeanFrançois Millet ve Adolph Von Menzel'in eserleri üzerine odaklanılmıştır. Bu kapsamda araştırmada, Gustave Courbet'nin Taş Kırıcılar, Jean-François Millet'nin Hasatçılar ve Adolph Von Menzel'in Demir Haddehanesi adlı eserleri incelemeye alınmış, söz konusu eserlerin görsel anlam katmanlarında yer alan iletilerin sosyolojik anlatılarla ilişkileri değerlendirilmeye çalışılmıştır.

\section{Yöntem}

$\mathrm{Bu}$ araştırmada, görsel sanat eserlerinin anlam katmanlarını çözümlemeye olanak sağlayan göstergebilim anlam çözümleme aşamalarından yararlanılmıştır. Göstergebilimsel çözümleme, görüntüsel göstergeleri çözümlemeye ve görsel sanat eserlerinin anlam katmanlarıyla ilgili veri elde etmeyi olanaklı kılar (Ertan \& Sansarcı, 2016, Günay, 2008, 2012; Küçükerdoğan, 2012). Araştırmaya konu olan realist sanatçıların eserlerine yönelik göstergebilimsel çözümlemeler, Günay (2002) çalışmasında belirtiği betimsel, anlatımsal ve izleksel düzeylerde gerçekleștirilmiştir. Söz konusu göstergebilim çözümleme aşamalarının görsel sanat eserlerinde uygulamasına yönelik olarak ise Günay'ın (2008) çalıșmasından yararlanılmıștır. Bu bağlamda çözümlemenin betimsel düzeyinde, sanat eserindeki göstergelerin gerçek dünyadaki karşllıkları ve eserin temel özelliklerinin betimlendiği; anlatısal düzeyde, ilk aşamada ortaya konulan anlatısal ögelerin incelendiği ve anlatımın işleyiş biçiminin ortaya konulduğu; izleksel düzeyde ise yan anlam ve derin anlamı oluşturan yapıların incelendiği görülmektedir (Günay, 2008, s. 19-22). Günay $(2002,2008)$ çalışmalarında ortaya koyduğu söz konusu göstergebilim anlam çözümleme aşamalarından yararlanarak bu araștırmada, Gustave Courbet'nin Taş Kırıcılar, Jean-François Millet'nin Hasatçılar ve Adolph Von Menzel'in Demir Haddehanesi adlı eserlerinde yer alan görüntüsel göstergelerin düz anlam, yan anlam ve derin anlam gösteren gösterilen örüntülerinin çözümlemesi gerçekleştirilmiştir. Göstergebilimde yaygın olarak karşılaşılan (Erkman, 1987, s. 44) ve bu araştırma kapsamında da yararlanılan gösterge şeması şu şekildedir:

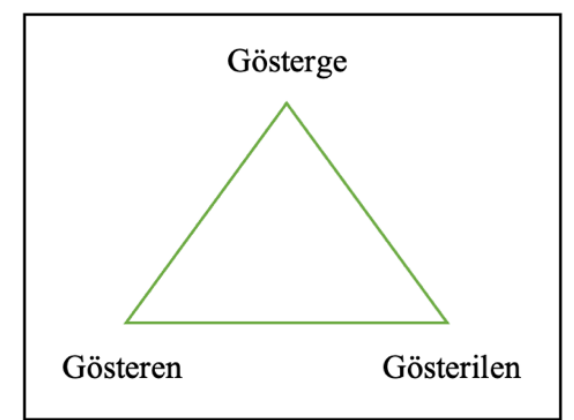

Görsel 1. Göstergebilim Gösterge Șeması

Görsel sanat eserlerine yönelik göstergebilimsel çözümleme çalışmalarıyla ilgili olarak soyut sanat kategorisinde (bkz. Günay, 2008), natüralist (yansıtmacı) kategoride (bkz. Küçükerdoğan, 2012) ve kavramsal sanat kategorisinde (bkz. Soylu, 2020; Yllmaz, Demir Yllmaz \& Yllmaz, 2021) vb. yer alan 
sanat eserlerinin görüntüsel gösterge yapıları üzerine odaklanan çeşitli incelemelerle karşılaşılmaktadır. Göstergebilimsel çözümlemeye konu olan görüntüsel göstergelerin yoruma açık bir özellik göstermesi, çözümleme sürecini şekillendiren temel özelliklerden biri olarak karşımıza çıkmaktadır. Konuyla ilgili Eco (2016) çalışmasında enformel sanat (resim) olarak ifade etiği açık yapıt özelliklerini geniş yorum ve okumalara imken veren bir özellik olarak değerlendirdiği görülmektedir. Bu anlamda soyut resimlerin görüntüsel göstergeleri göstergebilimsel açıdan çok yönlü okumalara olanak sunarken, realist sanat eserlerindeki görüntüsel göstergeler ise temsilin arka yapısındaki anlamları (yan ve derin anlamları) keşfetmek adına bağlam temelli okumalara olanak sunabileceği düşünülmektedir. Bu düşünceden hareketle araștırmaya konu olan eserlerin içerdikleri görüntüsel göstergeler sanat sosyolojisi ve görsel sosyoloji bağlamında göstergebilimsel olarak çözümlenmiş; söz konusu bağlam/analoji temelinde eserlerdeki göstergelerin yan ve derin anlam iletileri ortaya çıkarılmaya çalışılmıştır.

Araştırmada göstergebilimsel çözümlemelere ek olarak literatür taramasından da yararlanılmıştır. Karasar'ın (2017) belirttiği gibi literatür taraması bir tür belgesel tarama olarak değerlendirildiğinde, araştırmalarda yaygın olarak yararlanılan bir veri toplama tekniği olarak karşımıza çıkar. Bu bağlamda, araştırma bulgularında göstergebilimsel çözümlemeleri desteklemek amacıyla alanyazını oluşturan yazılı materyallerin (kitap, makale, manifesto yazıları vb.) içerdiği bilgilere de yer verilmiştir.

\section{Bulgular}

Bu bölümünde araştırmaya konu olan Gustave Courbet'nin Taş Kırıcılar, Jean-François Millet'nin Hasatçılar ve Adolph Von Menzel'in Demir Haddehanesi adlı eserlerinin göstergebilimsel çözümlemelerine yer verilmiştir.

\section{Gustave Courbet'nin Taş Kırıcılar'ı Üzerine Çözümleme}

Sanat tarihi literatürüne 'realizm' terimini kazandıran ve realizm sanat akımının öncü sanatçllarından birisi olan Fransız ressam Gustave Courbet [1819-1877], resimlerinde işlediği konular, üslup anlayışı ve sahip olduğu sanatçı kimliği gibi özellikler çerçevesinde konu üzerinde karşımıza çıkan ikonik bir sanatçıdır. Sanat tarihinde figüratif resimleriyle öne çıkan Courbet'nin, figüratif kompozisyonların yanı sıra peyzaj (manzara) ve natürmort (ölü doğa) türlerinde resimleriyle de karşılaşılmaktadır. Realizm ile özdeşleşen Courbet'nin, 1849-50 yılında tamamladı̆̆ı ve II. Dünya Savaşıı dolaylarında yok edilen Taş Kırıcılar (The Stonebreakers) adlı figüratif resmi, sanatçının sanatsal anlayışının genel özelliklerini temsil eden eserlerinden biri olma özeliği göstermektedir. $\mathrm{Bu}$ nedenle araştırmada Courbet'nin Taş Kırıcılar adlı çalışması üzerine odaklanılarak göstergebilim anlam çözümleme aşamalarıyla eser incelenmiştir. 


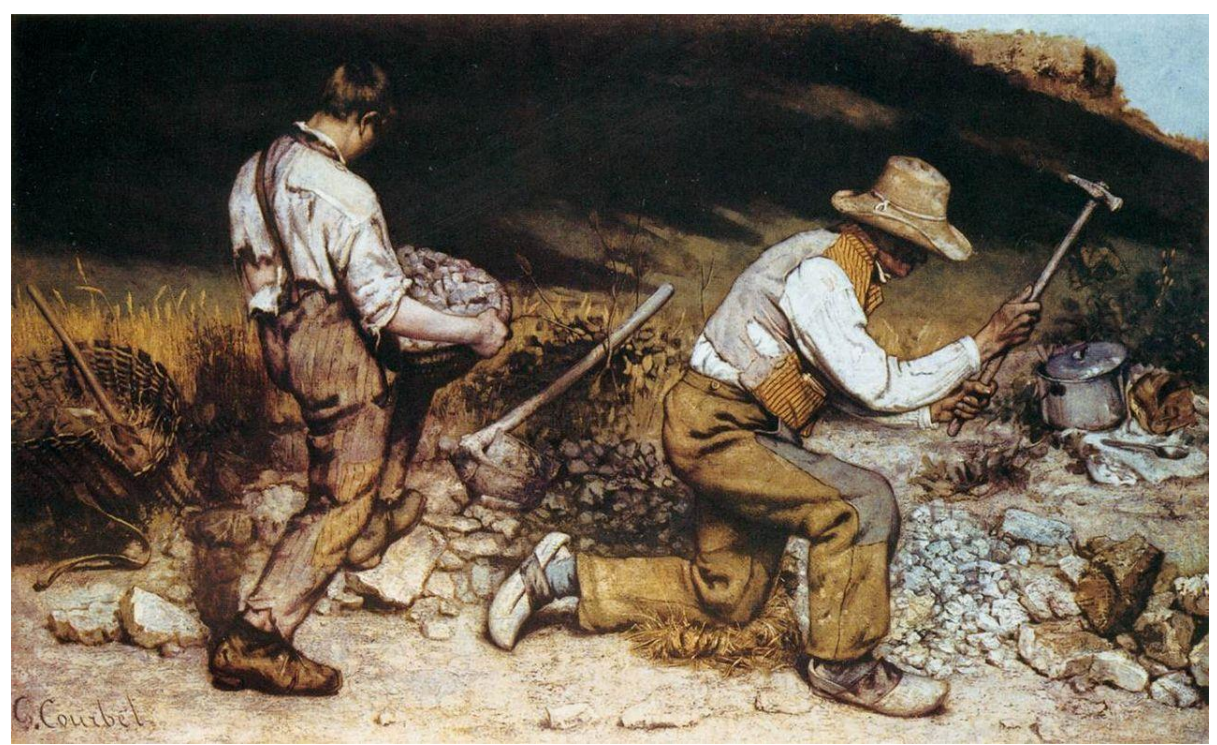

Görsel 2. Gustave Courbet, Taş Kırıcılar (The Stonebreakers), 1849-50, Tuval Üzerine Yağlıboya, 165 x 257 cm. II. Dünya Savaşı Dolaylarında Yok Edildi.

https://en.wikipedia.org/wiki/The_Stone_Breakers\#/media/File:Gustave_Courbet__The_Stonebreakers_-_WGA05457.jpg sayfasından erişilmiştir.

Yukarıda Görsel 2'de yer alan Taş Kırıcılar adlı eserde gözlemlenen görüntüsel göstergeler arasında işçiler, yırtık ve yamalı kıyafetler, balyoz, başak, tencere, kaşık, sepet, taş parçaları ve kimliği gizlenmiş yüzler yer almaktadır. Söz konusu göstergelere ilişkin düz anlam, yan anlam ve derin anlam çözümleri şu şekildedir:

\begin{tabular}{|c|c|c|c|}
\hline Gösterge & Düz Anlam & Yan Anlam & Derin Anlam \\
\hline İşçiler & Çalışan & Emekçiler & İşçi Sınıfı (Proletarya) \\
\hline $\begin{array}{l}\text { Yırtık ve Yamalı } \\
\text { Kıyafetler }\end{array}$ & Yıpranmışlık & Ekonomik Yetersizlik & Alt Sinıf \\
\hline Balyoz & Kırıcı Alet & Statü, Güç, Otorite & Burjuvazi \\
\hline Başak & Kılçıklı Bitki Başı & Bereket & İnanç Sistemi \\
\hline Tencere & Pișirme Kabı & \multirow[b]{2}{*}{ Aş/Yemek } & \multirow[b]{2}{*}{ Fizyolojik İhtiyaç } \\
\hline Kaşık & $\begin{array}{l}\text { Yemek Yemeye } \\
\text { Yardımcl Araç }\end{array}$ & & \\
\hline Sepet & Tașıma Kabı & Bir Arada Tutmak & Kırsal Yașam \\
\hline Taș Parçaları & Çakıl & Topluluk & Ayrıștırmak \\
\hline $\begin{array}{l}\text { Kimliği Gizlenmiş } \\
\text { Yüzler }\end{array}$ & Belirsiz Suretler & Gizem & Sinıfsallaştırma \\
\hline
\end{tabular}

Görsel 3. Taş Kırıcılar’a Yönelik Göstergebilim Anlam Çözümleme Şeması

Courbet'in Taş Kırıcılar adlı eserinde yer alan görüntüsel göstergelerin derin anlam ifadelerinden anlaşıldığı üzere (Görsel 3), bu ifadelerin büyük çoğunluğunun sosyolojinin araştırma konuları arasında yer alan kavramlarla ilgili olduğu görülmektedir. Courbet söz konusu resminde her ne kadar günlük yaşamın sıradan bir anını konu itibariyle işlemiş olsa da resimde yer alan göstergelerin yan anlam ve derin anlam ifadelerinden yararlanarak, resmin dönemin toplumsal düzenine yönelik olarak eleştirel anlatımlar sunduğu ifade edilebilir. Bu çerçevede resmi daha kapsamlı olarak çözümlemek gerektiğinde ise öncelikli olarak Kjellman-Chaplin'in (2015) belirtiği gibi Courbet'nin Taş Kırıcılar'ının merkezinde yer alan iki figür tasvirinin ve resmin genel üslubunun anti-akademik bir özellik gösterdiği; resmin, figürleri idealize etme ya da onlara yüksek bir değer atfetme gibi akademik beklentilere ters düșen bir anlayışla oluşturulduğu görülmektedir. Resmin merkezinde yer alan bu iki figürün sergiledikleri eylem (taş kırma eylemi), izleyicilerin figürleri 'işçiler' olarak tanımlamasına olanak sunmaktadır. Bu anlamda resimdeki iş̧̧iler göstergesi, yan anlam açısından emekçiler kavramını, derin anlam açısından ise bir sosyal sınıf tabakası olarak işçi sınıfına 
(proletarya) yönelik iletiler içermektedir. Taș Kırıcılar'da olduğu gibi Courbet'in resimlerinde genel olarak, Honour ve Fleming'in (2016) belirtiği gibi sıradan konular ve taşra toplumunun çeşitli katmanlarından insanların resmedildiği gözlemlenir. Courbet'nin günlük yaşamın sıradanlığını/doğallı̆̆ını resimlerine yansıtması, izleyicinin resimde işlenen tasvirler ile dünyevi olan arasında sıkı bir iliş̧ki kurmasına neden olmaktadır. Bu ilişki, resimdeki anlatımın gücünü arttırmaya ve resmin konusunun dünyevi olaylara yönelik toplumsal eleștirel bir özellik kazanmasına neden olduğu düşünülmektedir.

Taş Kırıcılar'da gözlemlenen bir diğer gösterge yırtık ve yamalı kıyafetlerdir. Düz anlam açısından yıpranmışlı̆̆ temsil eden bu gösterge, yan anlam ve derin anlam iletileri bakımından sosyoekonomik durumlar hakkında izleyiciye çeșitli iletiler sunmaktadır. Bu noktada, yırtık ve yamalı kıyafetlerin yan anlamı ekonomik yetersizliği; derin anlamı ise toplumun alt sınıf tabakasına yönelik iletiler içerdiği ifade edilebilir. Yırtık ve yamalı kıyafetler göstergesi; iş̧̧ilerin yaşam ve çalışma şartlarındaki zorluklar, ekonomik gelir düzeyinin fizyolojik ihtiyaçlara yansımaları, toplumsal tabakalaşmanın sınıflar üzerindeki etkileri vb. konular hakkında fikir sahibi olabilmeye yardımcı derin anlam iletilerini karşımıza çıkarmaktadır. Benzer şekilde resimde üzerine odaklanılan balyoz göstergesinin yan anlam iletisinin statü, güç ve otoriteye; derin anlam iletisinin ise burjuvaziye karşıllk geldiği düşünülmektedir. Bu nedenle balyoz göstergesinin, toplumsal yapının alt ve üst sınıflarıyla ilgili olarak proletarya ve burjuvazi ilişkisine dair anlatılar içerdiğini ifade etmek mümkündür. Ek olarak balyoz göstergesi, toplumsal yapıda etkileri hissedilen tahakküm biçimlerine yönelik olarak da derin anlam iletilerinde bulunmaktadır. Yine, resimde incelemeye konu olan bir diğer gösterge ise başaktır. Başak göstergesinin, yan anlam açısından bereketi; derin anlam açısından ise inanç sistemini ifade ettiği düşünülmektedir. Bu anlamda başağın, iş̧̧ilerin alın teriyle kazandıkları helal malın ve emeğin mükâfatına yönelik Tanrı katından bahședilen nimetlerin bir göstergesi olduğu ifade edilebilir. Başak göstergesine eşlik eden tencere ve kaşık göstergeleri de yan anlam açısından aş/yemeğe; derin anlam açısından fizyolojik ihtiyaçlara yönelik anlamlar içerdiği görülmüştür. Tencerenin kapağının bir miktar açı şekilde resmedilmiş olması, izleyici üzerinde tencerenin içinin boş olduğu yönünde bir algı meydana getirmektedir. Bu nedenle tencere göstergesi fizyolojik ihtiyaçları karşılamaya yönelik iş, emek ve çalışma eylemlerine yönelik anlatımlar sunduğu düşünülmektedir. Bu bağlamda resimde yer alan yırtık-yamalı kıyafetler, başak, tencere ve kaşık göstergelerinin, iş̧̧i sınıfının toplumsal konumu hakkında eleştirel nitelikli sorgulamalara kapı acıttığı; işçilerin emek, alın teri ve ağır çalışma şartlarının günlük yaşam içerisindeki yeri ve önemine yönelik olarak sosyolojik bir farkındalık oluşturmaya aracılık ettiği görülmüştür.

Courbet'in Taş Kırıcılar'ında incelemeye konu olan diğer göstergeler ise sepet, taş parçaları ve kimliği gizlenmiş yüzlerdir. Bu kapsamda sepet göstergesinin yan anlam açısından bir arada tutmayı, derin anlam açısından kırsal yaşamı temsil ettiği; taş parçaları göstergesinin yan anlam açısından topluluğu, derin anlam açısından ayrıştırma eylemini temsil etiği; son olarak kimliği gizlenmiş yüzler göstergesinin ise yan anlam açısından gizemi, derin anlam açısından ise sınıfsallaştırmayı temsil ettiği düşünülmektedir. Yan ve derin anlam iletileri açısından bu göstergelerin, resmin konusuyla bağlantılı olarak toplumsal yapıyı oluşturan gruplara yönelik sınıfsal bir yaklaşımın özelliklerini karşımıza çıkarmaktadır. Özellikle derin anlam çözümlemesinde karşımıza çıkan ayrıştırma ve sınıfsallaştırma iletilerinin, resmin yapıldığı dönemin toplumsal koşullarında iş̧̧i sınıfı üzerindeki hegemonik (baskıcı) etmenlere ilişkin siyasal oluşumlar hakkında sosyolojik değerlendirmelere olanak sağlamaktadır.

\section{Jean-François Millet'nin Hasatçılar'ı Üzerine Çözümleme}

Gustave Courbet'nin ardından realizm sanat akımının temsilcileri arasında yer alan bir diğer önemli isim Fransız ressam Jean-François Millet'dir [1814-1875]. Millet'nin figüratif ve peyzaj ilişkisi üzerine kurulu kompozisyonlarında kırsal kesim ve köy yaşamına dair tasvirlerle karşılaşılmaktadır. Barbizon Okulu üyelerinden birisi olarak Millet'nin resimlerinin doğalcılık ve gerçekçilik arasında bir konuma sahip olduğu bilinmektedir (Krausse, 2005, s. 65). Bu konuda Millet'nin 1857 tarihli Hasatçılar adlı çalışması, sanatçının en bilindik eserlerinden biri olarak karşımıza çıkar. Bu nedenle araştırmada Millet'in Hasatçılar adlı çalışması üzerine odaklanılarak göstergebilim anlam çözümleme aşamalarıyla eser incelenmiştir. 


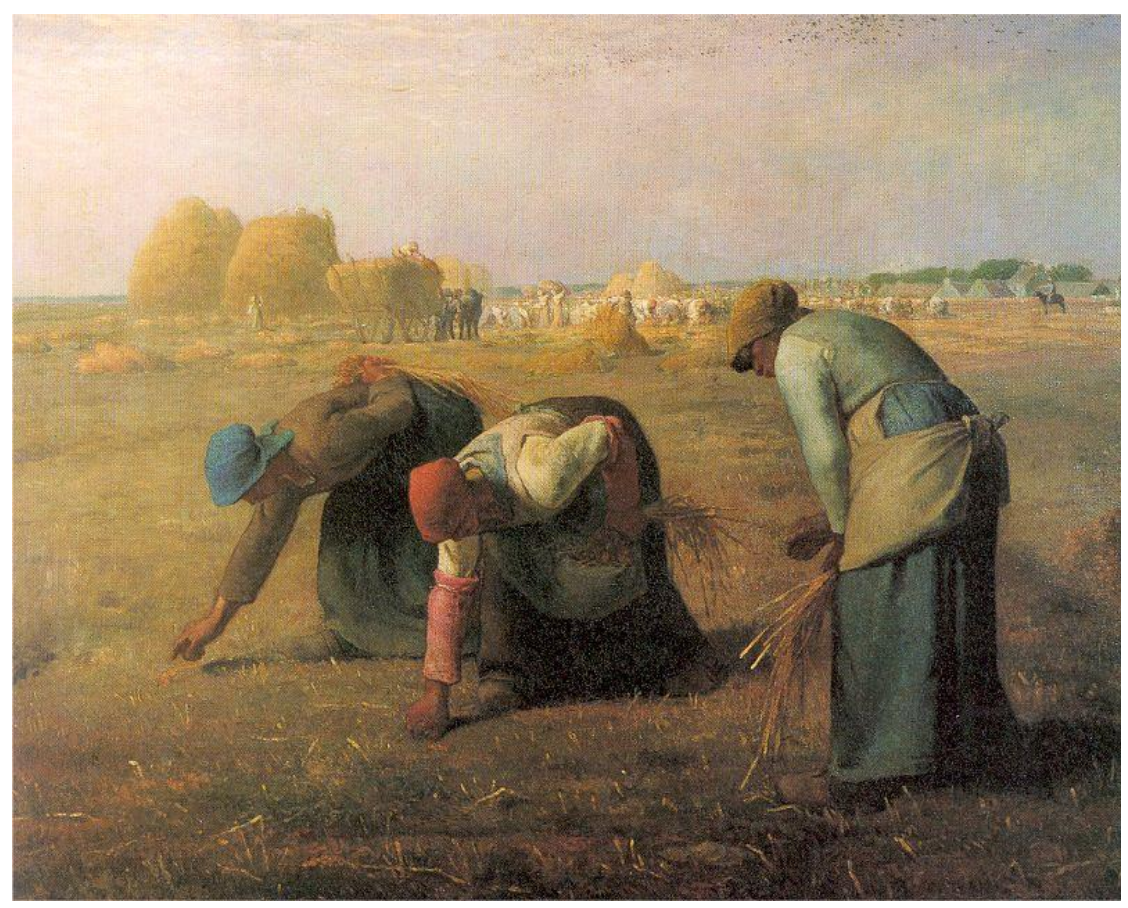

Görsel 4. Jean-François Millet, Hasatçılar (The Gleaners), 1857, Tuval Üzerine Yağlıboya, 83,5 x 110 cm. II. Musée d'Orsay, Paris.

https://upload.wikimedia.org/wikipedia/commons/6/64/Millet_Gleaners.jpg sayfasından erişilmiştir.

Yukarıda Görsel 4'de yer alan Hasatçılar adlı eserde gözlemlenen görüntüsel göstergeler arasında üç köylü kadın, buğday sapları, saman yığınları, at arabası, çiftçiler, at üstünde bir figür (atlı) ve evler yer almaktadır. Resimdeki görüntüsel göstergelere ilişkin düz anlam, yan anlam ve derin anlam çözümleri şu şekildedir:

\begin{tabular}{llll}
\hline Gösterge & Düz Anlam & Yan Anlam & Derin Anlam \\
\hline Köylü Kadınlar & Çiftçiler & Emekçiler & İşçi Sınıfı (Proletarya) \\
\hline Buğday Sapları & Bitki Gövdesi & Hasat & Bereket \\
\hline Başörtüsü & Eşarp & Mahremiyet & $\begin{array}{l}\text { İnanç } \\
\text { Sistemi/Muhafazakârlık }\end{array}$ \\
\hline $\begin{array}{l}\text { Ahşap Terlik (Sabo } \\
\text { Terlik) }\end{array}$ & Yazlık Ayak Giysisi & Dayanıklılık & Alt Sınıf Giysisi \\
\hline Saman Yığınları & Hasat & Bereket & İnanç Sistemi \\
\hline At Arabası & Ulașım Aracı & Nostaljik Gezinti & Romantizm \\
\hline Atlı & Ata Binen Kimse & Atlı Asker & Ağa/Derebeyi \\
\hline Evler & Yapı & Yerleșke & $\begin{array}{l}\text { Yerleşik Hayat } \\
\text { Sedentizm) }\end{array}$ \\
\hline
\end{tabular}

Görsel 5. Hasatçılar’a Yönelik Göstergebilim Anlam Çözümleme Şeması

Millet'nin Hasatçllar adlı eserinde yer alan görüntüsel göstergelerin derin anlam iletilerinin büyük çoğunluğunun (Görsel 5), eseri sosyolojik olarak irdelemeyi mümkün kılan kavramlara ve iletilere karşılık geldiği görülmektedir. Resmin merkezinde yer alan işçi sınıfına ait üç köylü kadın figürü ile izleyicilere, dönemin sosyal sınıf tabakalarına yönelik eleştirel nitelikli bir bakış sunulmaya çalışılmaktadır. Konuyla ilgili olarak Millet'nin, işçi sınıfını resmetmekte uzmanlaşan (Honour \& Fleming, 2016, s. 669) ve ișçi sınıfına ait bireyleri (ișçileri) bir nesne olarak ilk defa sanatın içerisine dâhil eden (Krausse, 2005, s. 65) ressamlardan birisi olduğu ifade edilir. Hasatçllar'da gözlemlenen görüntüsel göstergelerin yardımıyla eser daha kapsamlı olarak incelendiğinde ise resmin 
merkezindeki üç köylü kadın figürünün çiftçi kadınları temsil ettiği; köylü kadın göstergelerinin işçi sınıfını (proletaryayı) yücelten derin anlam iletisine karşıllı geldiği anlaşılmıştır. Resimde köylü kadın göstergeleriyle işçi sınıfına çekilen dikkatler üzerinde resimde kullanılan renklerin de önemli rollerinin bulunduğu düşünülmektedir. Bu düşünceden hareketle resimde kullanılan sıcak renklerin oluşturduğu romantik izlenimin, günün son dakikalarında hasatçlların yorgunluklarının üzerini örten ve hasatçıları kentsel insanlardan daha özel bir konuma taşımaya yardımcı bir duyum meydana getirdiği ifade edilebilir. Bu yorumla ilişkili olarak Hauser (2006) çalışmasında "Millet, fiziksel güçle yapılan iși yüceltir ve köylüyü yeni bir destan kahramanı yapar" (s. 246) şeklinde belirtmiștir. Benzer şekilde, Honour ve Fleming (2016) çalışmasında Millet'nin resimleri, tarımda makineleşmenin karıştı olarak insan emeğini ve iş gücünü yüceltmesi nedeniyle döneminde büyük ilgiyle karşılandığını belirtir. Millet'in resimlerindeki bu özellikler, onun resimlerini romantizmden ayran en önemli faktörlerden birisi olarak karşımıza çıkmaktadır.

Resmin merkezinde yer alan iş̧̧i sınıfına ait üç köylü kadın figürüyle ilişkili olarak incelemeye konu olan diğer göstergeler arasında çiftçi kadınların ellerinde tuttukları buğday sapları, kadınların başörtüleri ve ahşap terlikleri (sabo terlik) yer almaktadır. Söz konusu gösterge dizgelerinin yan anlam ve derin anlam iletileri, sanayileşme karşıtı politik bir söylemi karşımıza çıkarmaktadır. Bu noktada buğday sapları göstergesi, insanlık tarihinin kadim ve en faydalı besin kaynağına yönelik gerçekleștirilen hasadı ve hasat işlemi sonucunda elde edilen bereketi temsil ettiği düşünülmektedir. Buğdayın yüzyıllardır (sanayileşme öncesi dönemde) insan eliyle ekilip hasat edilmesi nedeniyle resimdeki buğday sapları göstergesi, sanayileşme ve kentleşme karşısında insan emeğini vurgulaması açısından önem arz etmektedir. Buğday sapları göstergesinden sonra resimde değerlendirmeye konu olan bir diğer gösterge başörtüsüdür. Çiftçi kadınların eşarp olarak kullandıkları başörtüsü, yan anlam açısından mahremiyetine düşkün bir topluluğun varlığını temsil ederken; derin anlam açısından ise inanç siteminin özellikleri hakkında izleyiciye görsel anlatılarda bulunmaktadır. Bu gösterge üzerinden, Fransız halkına mensup alt sınıf tabakasında yer alan insanların Hristiyan diniyle olan ilişkileri, mahremiyete verilen önem ve muhafazakâr bir topluluğun yaşam biçimlerine yönelik iletiler elde edilebilmektedir. Son olarak çiftçi kadınların ayaklarına giydikleri ahşap terlikler (sabo terlik) görüntüsel bir gösterge olarak ele alındığında, bu terliklerin derin anlam iletisinin sınıfsal bir özelliği karşımıza çıkardığı görülmektedir. Ahşap terliklerin işçiler tarafından hasat işleminde kullanılıyor olması bu terliklerin ucuz malzemeden üretildiği fakat dayanıklı ve uzun ömürlü olduğu yönünde bir izlenim meydana getirmektedir. Bu düşünceden hareketle resimde ahşap terliklerin hasatçılar tarafından ortak şekilde kullanılıyor oluşu da bu terliklerin bir alt sınıf giysisi derin anlam iletisini karşımıza çıkarması noktasında belirleyici olmuştur.

Resmin merkezindeki üç figürü çevreleyerek resmin kompozisyonunu oluşturan diğer göstergeler arasında saman yığınları, at arabası, atlı ve ev yer almaktadır. İncelemeye konu olan söz konusu gösterge dizgeleri, resmin ana konusunu desteklemeye yardımcı bilgi objeleri özelliği göstermektedir. Bu göstergelerden saman yığınlarının, düz anlam açısından hasat işlemini; yan anlam aşısından bereketi temsil ettiği düşünülmektedir. Hasat ve berekete yönelik çağrışımlar içermesi nedeniyle resimdeki saman yığınlarının, derin anlam açısından inanç sitemine yönelik iletilerde bulunduğu ifade edilebilir. Resimde yeni hasat edilmiș saman yığınları göstergesi, Tanrı'nın önemli bir besin kaynağı olarak insanlara sunduğu buğday rahmetiyle ilişkilendirilebilir. Saman yığınları göstergesinin ardından resimde incelemeye konu olan bir diğer gösterge at arabasıdır. At arabası göstergesi düz anlam açısından ulaşım aracı, yan anlam açısından ise nostaljik gezinti şeklinde yorumlanmıştır. Bu göstergenin yan anlam karşılığından hareketle derin anlamının romantizmi ifade etti düşünülmektedir. Bu çözümlemeye kaynaklık eden nedenler arasında, kimi romantik sanatçıların -John Constable'ın Saman Arabası (The Hay Wain), Robert Ladbrooke'un Ağaç Manzara (Wood Scene), John Crome'un Eski Yol Değirmeni (The Old Windmill) vb. örneklerdeki gibiyoğun manzara atmosferinin içerisinde at arabasına yer vererek duyguları harekete geçirme girişimleri bulunmaktadır. Bu düşünceden hareketle at arabası göstergesinin derin anlam iletisi olarak romantizmin, resimde yoğun olarak gözlemlediğimiz ideolojik ve eleștirel görsel anlatımlarla zıt bir özellik gösterdiğini ifade etmek mümkündür. Resimde toplumsal eleştiri niteliği gösteren ve incelemeye konu olan bir diğer gösterge atlı figürüdür. Resmin merkezindeki çiftçi kadınlara göre oldukça geri planda resmedilmiş bu figürün derin anlam karşılığı, dönemin toplumsal özellikleri hakkında izleyiciye bir takım bilgiler vermektedir. Resimde atlı figürü, hasatçıların çalışmalarını kontrol eden ve hasat işlemine hâkim bir pozisyonda izliyor şeklinde resmedilmiştir. Bu nedenle atlı 
figürünün derin anlam iletisinin ağa/derebeyine karşllı geldiği düşünülmektedir. Ağa/derebeyi derin anlamı, dönemin toplumsal yapısında yerel otoriter güçlerin varlığına dair izlenimler elde etmeye olanak sağlamaktadır. Son olarak resimde incelemeye konu olan gösterge evlerdir. Resimde evler, peyzajın en arka bölümünde ve ufuk çizgisine paralel şekilde konumlandırılmıștır. Ev göstergesinin, belirli bir coğrafyada yaşayan insan topluluklarının yașam șekilleri hakkında bilgiler elde etmeye olanak sağladığı düşünülmektedir. Peyzajın arka bölümünde resmedilmiş olan ev siluetlerinin, yerleşik hayata (sedentizm) dair derin anlam iletileri sunduğu görülmüştür. Bu anlamda ev göstergesinin, dönemin kırsal yaşam koşulları hakkında sosyolojik çıkarımlar yapmaya olanak sağladığı ifade edilebilir.

\section{Adolph Von Menzel'in Demir Haddehanesi Üzerine Cözümleme}

Alman realist sanatçı Adolph Von Menzel [1815-1905] resimlerinde işlediği toplumsal içerikli konularla karşımıza çıkan ressamlardan birisidir. Menzel'in resimleri tarihsel konular üzerine odaklanan toplumcu gerçekçi bir özellik gösterir. Konuyla ilgili Kohle (2007) çalışmasında Menzel'in kariyerinin ilk yirmi beş yılının onun tarihi konulara olan ilgisi üzerine şekillendiğini ifade eder. Tarihsel olaylar, halka ait değerler, gelenek ve göreneğe dair ritüeller, sınıfsal ilişkiler vb. konular, Menzel'in resimlerinde tüm gerçekliğiyle işlenmektedir. Menzel ile ilgili olarak Turani (2010) çalışmasında "o, tarihin "gerçekte olduğu gibi" anlatılmasını önemsiyordu" (s. 512) şeklinde belirtmiş, sanatçının gerçekç̧i anlatıma olan bağlılığını vurgulamıştır. Bu konuda özellikle Menzel'in Büyük Friedrich'i konu alan resimlerinin, titiz bir tarih araștırma süreci sonunda Prusya devleti ve Berlin Akademisi'nin onaylarıyla gerçekleştirildiği ifade edilmektedir (Honour \& Fleming, 2016, s. 672). Boime'nin (2007) çalışmasında gerçekleștirilen incelemeler ışığında Menzel'in estetik, sosyal, politik ve tarihsel özellikler gösteren çalışmalarının Berlin'de yaşanan toplumsal olayların etkisinde gerçekleştiği ve bu olayları konu edindiği anlaşılmaktadır. Bu bağlamda Menzel'in resimlerindeki görsel anlatımın, realizm kapsamında sanat-toplum etkileşimini anlamlandırma konusunda önem arz ettiği düşünülmektedir. Bu düşünceden hareketle Menzel'in sanat anlayışını en açık şekilde temsil eden resimlerden biri olarak Demir Haddehanesi adlı eser, bu araştırma kapsamında göstergebilim anlam çözümleme çalışmasıyla incelenmiştir. 


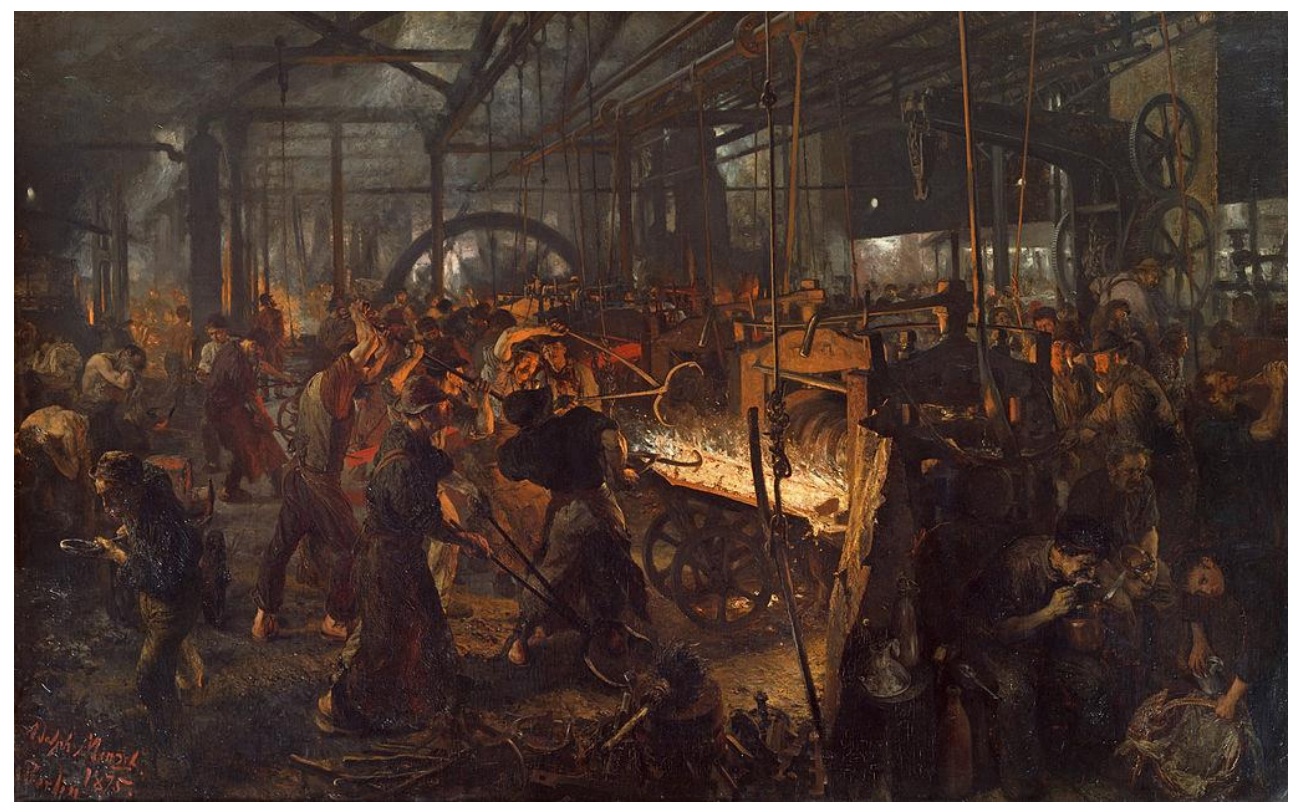

Görsel 6. Adolph Von Menzel, Demir Haddehanesi (Eisenwalzwerk), 1872-75, Tuval Üzerine Yağlıboya, 158 x $254 \mathrm{~cm}$. Staatliche Museen zu Berlin, Berlin.

https://upload.wikimedia.org/wikipedia/commons/thumb/4/4a/Adolph_Menzel__Eisenwalzwerk_-_Google_Art_Project.jpg/1024px-Adolph_Menzel_-_Eisenwalzwerk__Google_Art_Project.jpg sayfasından erişilmiştir.

Yukarıda Görsel 6'de yer alan Demir Haddehanesi adlı eserde gözlemlenen görüntüsel göstergeler arasında işçiler, makine, demir, ateş, dinlenmelik ve mutfak erzakları yer almaktadır. Söz konusu göstergelere ilişkin düz anlam, yan anlam ve derin anlam çözümleri şu şekildedir:

\begin{tabular}{llll}
\hline Gösterge & Düz Anlam & Yan Anlam & Derin Anlam \\
\hline İşçiler & Beceri Sahibi Kimse & Fiziksel Güç & Sosyalizm \\
\hline Makine & Alet & Üretim & Endüstrileşme \\
\hline Demir & Maden/Element & $\begin{array}{l}\text { Sağlamlık, } \\
\text { Dayanılılık }\end{array}$ & Güç, Statü \\
\hline Ateş & Sıcaklık & Ceza & Cehennem \\
\hline Dinlenmelik & İstirahat Alanı & Tembellik & Alın Teri \\
\hline Mutfak Erzakları & Kap Kacak & Aş/Yemek & Fizyolojik İhtiyaç \\
\hline
\end{tabular}

Görsel 7. Demir Haddehanesi'ne Yönelik Göstergebilim Anlam Çözümleme Şeması

Figüratif ve kalabalık bir kompozisyondan oluşan Adolph Von Menzel'in Demir Haddehanesi adlı büyük ölçekli resmi (Görsel 7), sanayi devriminin üretim süreçlerine ve iş hayatına yansımalarını en etkili şekilde tasvir eden eserlerden birisidir. Söz konusu resme yönelik gerçekleştirilen göstergebilim anlam çözümleme çalışması sonucunda resimdeki görüntüsel göstergelerin derin anlam iletilerinin büyük çoğunluğunun sosyolojik kavramlar ve iletilere karşllık geldiği görülmüştür. $\mathrm{Bu}$ bağlamda resimde kalabalık şekilde resmedilen iş̧̧iler göstergesi, resmin ana kurgusunu oluşturan ve resme yüklenen anlamları şekillendiren imgeler topluluğu şeklinde karşımıza çıkarmaktadır. Çağrışımsal açısından bakıldığında işçiler göstergesinin; düz anlam açısından beceri sahibi kimseyi, yan anlam açısından fiziksel gücü, derin anlam açısından ise sosyalizme yönelik görsel iletiler içerdiği ifade edilebilir. İşçiler göstergesinin söz konusu yan anlam ve derin anlam iletilerinin, konu itibariyle resmin toplumsal anlatısını güçlendirmeye yardımcı olduğu ve işçilerin çalışma ortamları hakkında bilgi elde etmeyi mümkün kıldığı düşünülmektedir. Menzel'in doğa ve toplumu olduğu gibi (gerçekliğe bağlı kalarak) resmetmesinin bir sonucu olarak Demir Haddehanesi'nde görsel iletilerin güçlü bir sanatsal ifade biçimiyle izleyiciye aktarıldığı görülür. İşçilerin hareketli 
halde resmedilmesi sanayi üretiminin büyük bir hızla gerçekleştiğine dair izlenimler sunmaktadır. Bu yönüyle resim, sanayi devrimi sonrası meydana gelen yeni dünya gerçekliğine yönelik farklı bir bakış sunar (Krausse, 2005, s. 67). Demir haddehanesinde işçilerin yoğun çalıșma şartlarına nasıl dayandıkları, makine karşısında insan gücünün ve emeğinin değeri, sosyal sınıflar arasındaki fırsat ve hak eşitliği vb. konuların, söz konusu iş̧̧iler göstergesi üzerinden gerçekleştirilebilecek sorgulamalar arasında yer aldığı ifade edilebilir. Bu tür sorgulamaların temelinde ise işçiler göstergesinin derin anlamında yer alan sosyalizm teorisine yönelik iletiler bulunmaktadır.

Resmin konusunu teşkil eden işçiler göstergesinin ardından incelemeye konu olan bir diğer gösterge makinedir. Makine göstergesi, işçiler göstergesinin ardından resimde dikkat çeken bir diğer bilgi objesidir. Çağrışımsal olarak makine göstergesinin; düz anlam açısından aleti, yan anlam açısından üretimi, derin anlam açısından ise endüstrileşmeyi ifade ettiği görülmektedir. Bu bağlamda makine göstergesinin yan ve derin anlam iletileri, resmin konusuyla bütünleşik bir özellik gösterir. Resimde ele alınan endüstrileşme olgusu makine göstergesi üzerinden anlam kazanmaktadır. Resimde ifade edildiği şekliyle üretim eylemlerinde makinelerden yararlanma durumu ve kalabalık/kolektif çalışma ortamının varlığı, sanayi (endüstri) yönünden gelişim gösteren bir toplumsal oluşumun -yeni sanayileşmekte olan toplumların- karakteristik özelliklerini temsil etmektedir. Yine resimde, üretim sürecinde bir enerji kaynağı olarak makinelerden yaralanma durumuna ek olarak sanayi devrimi öncesinde de olduğu gibi insan gücüne yönelik de atıflarda bulunulmaktadır. Haddehanede adeta köle gibi çalışan işçilerin varlığı, mekanik üretim sürecine geçişin tam manasıyla gerçekleşmediği endüstrileşmeye geçiş sürecine işaret ettiği düşünülmektedir.

Demir Haddehanesi'nde incelemeye konu olan diğer görüntüsel göstergeler arasında demir, ateș, dinlenmelik ve mutfak erzakları bulunmaktadır. Bu göstergelerden demirin; düz anlam açısından maden/element, yan anlam açısından sağlamlık/dayanıklılık, derin anlam açısından ise güç/statü anlamlarına karşılık geldiği görülmektedir. Demir göstergesinin derin anlam iletisi olarak güç/statünün, sanayileşmenin doğurduğu kapitalist rekabet ortamı ve bu rekabet ortamı içerisinde işçilerin iş gücü gerektiren yoğun çalışma şartlarında sahip oldukları rol ve sorumluluklara ilişkin sosyolojik bir okumayı karşımıza çıkarmaktadır. Resimde gözlemlenen ateş göstergesinin yan anlam iletisi olarak ceza ve derin anlam iletisi olarak cehennem ifadeleriyle, inanç sistemine dayalı okumaların gerçekleştirilebileceği düşünülmektedir. Ateş göstergesinin olumsuz hal ve durumları çağrıştırması, resimde ele alınan sanayileşme konusunu eleştirel bir yaklaşımla sorgulamaya olanak sunmaktadır. Bu sorgulamada ise demir göstergesinin derin anlamında yorumlamaya konu olan işçilerin ağır ve olumsuz çalışma koşullarıyla ilgili iletilerle karşılaşılmaktadır. Yine, demir ve ateş göstergelerinin işçiler üzerinde oluşturduğu söz konusu derin anlamlara, resimde incelemeye konu olan dinlenmelik ve mutfak erzakları göstergeleri de eşlik etmektedir. Resmin sağ alt bölümünde yer alan dinlenmelik göstergesinin derin anlamı alın teri dökmeyi ifade ederken, mutfak erzakları göstergesinin derin anlamı ise fizyolojik ihtiyaca yönelik iletiler sunmaktadır. Derin anlam iletilerinden yola çıarak her iki gösterge de zorlu çalışma şartlarına ve insan emeğine atıfta bulunmaktadır. Tüm bu değerlendirmelerle ilgili olarak Menzel'in Demir Haddehanesi adlı eserinin, sosyolojinin konusu içerisinde yer alan sosyalizm, sanayileşme (endüstileşme), güç/statü ve iş gücü konuları çerçevesinde şekillenen toplumsal olay ve olgularla ilgili görsel anlam katmanlarına sahip olduğu görülmüștür.

\section{Sonuç}

Sanat tarihinde realizm sanat akımının önde gelen temsilcileri arasında yer alan Gustave Courbet, Jean-François Millet ve Adolph Von Menzel'in eserleri üzerine gerçekleştirilen göstergebilimsel çözümleme çalışmalarıyla bu araştırmada, realist sanat eserlerindeki görsel anlatıların toplumsal olay ve olgularla iliş̧ileri incelenmeye çalışılmıştır. Realist sanatçıların sanat anlayışlarının, duyular dünyasına dair gerçeklikle -dünyevi gerçeklikle- olan sıkı ilişkileri, realizm kapsamında sanat-toplum etkileșimini sorgulamaya neden olmaktadır. Bu bağlamda araştırmada Gustave Courbet'nin Taş Kırıcılar, Jean-François Millet'nin Hasatçılar ve Adolph Von Menzel'in Demir Haddehanesi adlı eserleri üzerine gerçekleștirilen göstergebilim anlam çözümleme çalışmasıyla eserlerde gözlemlenen göstergelerin derin anlam iletilerinde yer alan sosyolojik anlatıların ortaya çıkarılması hedeflenmiştir. Göstergebilimsel çözümlemeler sonucunda, araştırmaya konu olan sanat eserlerinin üretildikleri dönemin toplumsal olay ve olgularına yönelik derin anlam iletileri içerdikleri 
anlaşılmıştır. Eserlerin anlam katmanlarında yer alan ve yorumlamaya konu olan başlıca sosyolojik söylemler arasında; toplumsal sınıf tabakaları (alt ve üst sınıf), toplum tipleri (tarım ve yeni sanayileşmekte olan toplumlar), sosyalizm, sanayi (endüstri) devrimi, inanç sistemi, işçi sınıfı (proletarya) vb. iletiler yer almaktadır. Bu iletilerle ilgili olarak incelemeye konu olan eserlerde ağırlıklı olarak işçi sınıfına yönelik anlatımlarla karşılaşılmaktadır. Resimlerdeki iş̧̧i göstergelerine yönelik gerçekleştirilen göstergebilimsel çözümlemeler sonucunda, eserlerde toplumsal tabakalașma ve sosyal eșitsizlik kavramları ekseninde derin anlam iletilerine ulașılmıștır. Toplum içerisinde insan gruplarının hiyerarşik olarak sıralanmasını (Macionis, 2015, s. 248) ve insan grupları arasındaki eşitsizliği (Giddens \& Sutton, 2016, s. 493) vurgulayan toplumsal tabakalaşma kavramının, söz konusu üç realist resimde de genel olarak işçi göstergeleri ve işçilerin ağır çalışma koşullarına ilişkin sunulan tasvirler ile anlam bulduğu görülmüştür. Özelde ise bu konu; Courbet'nin Taş Kırıcılar'ında doğrudan işçi anlatımı, Millet'nin Hasatçılar'ında tarım toplumu, Menzel'in Demir Haddehanesi eserlerinde ise yeni sanayileşmekte olan toplum özellikleri üzerinden gerçekleştirilen işçi (proletarya) anlatımlarıyla işlenmiștir. Yine, resimlerde sosyolojinin konusu içerisinde yer alan sanayileşmeye (endüstrileşmeye) yönelik görsel anlatılarla karşılaşılmıştır. Menzel'in Demir Haddehanesi adlı eseri sanayi devrimi konusu üzerine açık bir anlatım özelliği gösterirken; Courbet'nin Taş Kırıcılar'ı ve Millet'nin Hasatçılar'ında ise bu konu, emek gücü kavramı çerçevesinde eleştirel nitelikli derin anlam iletileri yoluyla karşımıza çıkmıştır. Resimlerdeki görüntüsel göstergelerin büyük çoğunluğunun derin anlam katmanlarında toplumsal olay ve olgulara yönelik eleştirel iletilerle karşılaşıldığı; bu nedenle incelemeye konu olan üç realist resminde eleştirel teori içerikli görsel anlatılar içerdiği sonucuna ulaşılmıștır. Realist sanatçıların yansıtmacı (mimesis) prensiplerinin, sadece formların görüntüsel gerçekliğini tasvir etme yönünde değil aynı zamanda toplumsal olay ve olguların dünyevi karşılıklarını en açık şekilde işleme konusunda da belirginlik gösteren bir tasvir anlayışı özeliğine sahip olduğu görülmüştür. Bu özelliğin, realist anlatımın eleștirel nitelikli sosyolojik bir özelik kazanması noktasında önemli rollere sahip olduğu anlaşılmıştır. Bu bağlamda realist sanat eserleri üzerinden gerçekleştirilecek sosyolojik ve tarihsel incelemelerle, eserin üretildiği dönemin sosyal tarihsel özellikleri hakkında bilimsel veriler elde edilebileceği düşünülmektedir. Realist sanat eserlerinin enformel eserlere göre öznel yorumlara daha kapalı bir özellik göstermesinin, söz konusu eserlerin görsel iletilerinden sosyoloji ve tarih araştırmalarında bir tür tarihsel belge ve görsel veri olarak yararlanılabileceği konusunu karşımıza çıkarmıştır.

\section{Kaynakça}

Antmen, A. (2013). Sanatçılardan yazarlar ve açıklamalarla 20. yüzyıl batı sanatında akımlar. İstanbul: Sel Yayıncılık.

Arnason, H. H., \& Mansfield, E. C. (2013). History of modern art: Painting, sculpture, architecture, photography (7th ed.). Upper Saddle River, NY: Pearson.

Boime, A. (2007). Art in an age of civil struggle, 1848-1871. Chicago: The University of Chicago Press,

Boucher, G., \& Watson, I. (2017). Introduction to a visual sociology of smaller nations in Europe. Visual Studies, 32(3), 205-211. doi:10.1080/1472586X.2017.1365462

Cipriani, R., \& Del Re, E. C. (2012). Imagination and society: The role of visual sociology. Cogn Process, 13(2), 455-463. doi:10.1007/s10339-012-0433-4

Eco, U. (2016). Açık yapıt (T. Esmer, Çev.). İstanbul: Can Sanat Yayınları.

Erkman, F. (1987). Göstergebilime giriş. İstanbul: Alan Yayıncılık.

Ertan, G. ve Sansarcı, E. (2016). Görsel sanatlarda anlam ve algı. İstanbul: Alternatif Yayıncllık.

Giddens, A., \& Sutton, P. W. (2016). Sosyoloji (M. Şenol, Çev.). İstanbul: Kırmızı Yayınları.

Günay, V. D. (2002). Göstergebilim yazıları. İstanbul: Multilingual Yabancı Dil Yayınları.

Günay, V. D. (2008). Görsel okuryazarlık ve imgenin anlamlandırılması. Art-e Sanat Dergisi, 1(1), 129. https://dergipark.org.tr/tr/pub/sduarte/issue/20720/221479 
Günay, V. D. (2012). Görsel göstergebilim ve imgenin anlamlandırılması. V. D. Günay, \& A. F. Parsa (Ed.), Görsel göstergebilim: Imgenin anlamlandırılması içinde (s. 11-54). İstanbul: Es Yayınları.

Harper, D. (2012). Visual sociology. New York, NY: Routledge.

Hauser, A. (2006). Sanatın toplumsal tarihi/cilt 2: Rokoko, klasisizm, romantizm, natüralizm, empresyonizm ve film çă̆ı (Y. Gölönü, Çev.). Ankara: Deniz Kitabevi.

Honour, H., \& Fleming, J. (2016). Dünya sanat tarihi (H. Abacı, Çev.). İstanbul: Alfa Yayınları.

Karasar, N. (2017). Bilimsel araștırma yöntemi: Kavramlar ilkeler teknikler. Ankara: Nobel Akademik Yayıncılık.

Kjellman-Chaplin, M. (2015). Realizm (Gerçekçilik). T. Melick (Ed.), Tarih boyunca sanat: Dünya sanat tarihinde üsluplar ve akımlar içinde (s. 228-229). İstanbul: Yapı Kredi Yayınları.

Kohle, H. (2007). The modernity of history painting: The case of Adolph Menzel. Intellectual History Review, 17(2), 135-151. doi: 10.1080/17496970701383621

Krausse, A. C. (2005). Rönesanstan günümüze resim sanatının öyküsü (D. Zaptcıoğlu, Çev.). Almanya: Literatür Yayıncılık.

Küçükerdoğan, R. (2012). Görsel iletişim, göstergeler ve anlam aktarımı: Görsel iletide "pencere" imgesi. V. D. Günay, \& A. F. Parsa (Ed.), Görsel göstergebilim: İmgenin anlamlandırılması içinde (s. 55-79). İstanbul: Es Yayınları.

Macionis, J. J. (2015). Sosyal tabakalaşma (A. Canatan, Çev.). Sosyoloji (V. Akan, Çev. Ed.) içinde (s. 248-271). Ankara: Nobel Akademik Yayıncılık.

Mallarmé, S. (1982). The impressionists and Edouard Manet. In F. Frascina, \& C. Harrison (Eds.), Modern art and modernism: A critical anthology (pp. 39-44). New York, NY: Westview Press.

Malpas, J. (1997). Realism. London: Tate Gallery Publishing.

Nochlin, L. (1989). The politics of vision: Essays on nineteenth-century art and society (1st ed.). Routledge. https://doi.org/10.4324/9780429495960

Pauwels, L. (2010). Visual sociology reframed: An analytical synthesis and discussion of visual methods in social and cultural research. Sociological Methods and Research, 34(4), 545-581. doi:10.1177/0049124110366233

Power, E. M. (2003). De-centering the text: Exploring the potential for visual methods in the sociology of food. Journal for the Study of Food and Society, 6(2), 9-20. doi:10.2752/152897903786769670

Soylu, R. (2020). Maurizio Cattelan'ın “Komedyen” adlı enstelasyonunun göstergebilim çözümlemesi. International Social Sciences Studies Journal, 6(68), 3771-3783. http://dx.doi.org/10.26449/sssj.2603

The Metropolitan Museum of Art. (2008). Gustave Courbet. Retrieved from https://www.metmuseum.org/exhibitions/listings/2008/gustave-courbet

Thompson, J. (2014). Modern resim nasıl okunur: Modern ustaları anlamak (F. Candil Çulcu, Çev.). İstanbul: Hayalperest Yayınevi.

Turani, A. (2010). Dünya sanat tarihi. İstanbul: Remzi Kitabevi.

Wagner, J. (2002). Contrasting images, complementary trajectories: sociology, visual sociology and visual research. Visual Studies, 17(2), 160-171. doi:10.1080/14725 86022000032233

Williams, R. R., \& Whitehouse, K. (2015). Photo elicitation and the visual sociology of religion. Rev Relig Res, 57, 303-318. doi:10.1007/s13644-014-0199-5 
Yılmaz, U., Demir Yılmaz, E. N., \& Yılmaz, M. (2021). Enstalasyon sanatında Doğu izleri üzerine göstergebilimsel bir inceleme: Heike Weber, Rudolf Stingel ve Martin Roth örnekleri. Art-e Sanat Dergisi, 14(27), 47-71. https://doi.org/10.21602/sduarte.869913

\section{Extended Abstract}

Realism refers to an artistic understanding in the sense of imitating/depicting the subject's sensations about the external world within an objective approach. Within the framework of this definition, although realism evokes the existence of a naturalist understanding in the human mind, it is necessary to consider realism as the opposite of naturalism, as Thompson (2014) points out. Regarding the subject, in his study, Krausse (2005) expressed realism as an essentially democratic understanding of art based on the rejection of the ideal, based on the expression of Gustave Courbet. It is seen that the attitudes of realist artists, who differ from the tendencies of classical and romantic artists to depict forms with an idealist approach, showed a feature in the mid-19th century to depict the ordinariness of daily life, social phenomena, and thoughts with all their clarity (Antmen, 2013, p. 12). In his study on this attitude of realist artists, Hauser (2006) pointed out that the depiction of daily life with all its clarity and rudeness in realism is not an innovation in the history of art; however, the fact that society should be handled without being transformed into an artificial fiction and the political attitude that art has gained as a result of this situation should be considered as an innovation.

The tendency of realist artists to depict the external world with all its clarity is a feature that makes it possible to obtain visual indicators that help to clarify the relations of realism with social events and phenomena and artistic and sociological evaluations that can be realized through realist artworks. In this sense, it is thought that the ideology of realist art can be associated with the principles of objectivity and mediocrity that photographic reality has. In this study, concerning the visual sociological studies (Cipriani \& Del Re, 2012; Boucher \& Watson, 2017; Harper, 2012; Pauwels, 2010; Power, 2003; Wagner, 2002; Williams \& Whitehouse, 2015) that we encounter in obtaining data containing social content through photographic images, the focus was on obtaining data through realist artworks.

This research aims to examine the relationship of visual narratives in realist artworks with social events and phenomena semiologically. In this research, which has the feature of art criticism, it was focused on Gustave Courbet, Jean-François Millet, and Adolph Von Menzel, who are among the leading representatives of the realism art movement. In this context, the work of Gustave Courbet's The Stonebreakers, Jean-François Millet's The Gleaners, and Adolph Von Menzel's The Iron Rolling Mill were examined in the study, and the relationship between the messages in the visual meaning layers of these works and sociological narratives was tried to be evaluated.

In this study, semiotics analysis stages that allow analyzing the meaning layers of visual artworks were used. The semiotic analyzes of the artworks of realist artists who were the subject of the research were carried out at the descriptive, narrative, and deep-structure specified in the study of Günay (2002). In this context, at the descriptive level of the analysis, the real-world equivalents of the indicators in the work of art and the basic characteristics of the work are described; at the narrative level, the narrative elements shown in the first stage are examined and the way the narrative works are revealed; at the deep-structure, the structures that make up the connotation and deep meaning are examined (Günay, 2008, pp. 19-22). In the research, the analysis of the patterns of the visual indicators in his works showing literal meaning, connotation, and deep meaning was carried out by using the semiotics meaning analysis stages revealed by Günay $(2002,2008)$ in his studies.

As a result of semiotic analyzes, it was understood that the artworks subject to the research contained deep meaning messages about the social events and phenomena of the period in which they were produced. Among the main sociological discourses that are included in the meaning layers of the works and are the subject of interpretation; social class strata (lower and upper class), types of society (agriculture and newly industrialized societies), socialism, the industrial revolution, belief system, working-class (proletariat), etc. messages are included. Regarding these messages, the artworks subject to the examination mainly contain narratives for the working class. As a result of the semiotic analyzes carried out for the worker indicators in the paintings, deep meaning messages were reached in the artworks in the axis of the concepts of social stratification and social inequality. The concept of social stratification, which emphasizes the hierarchical ordering of human groups in the society (Macionis, 2015, p. 248) and the inequality between human groups (Giddens \& Sutton, 2016, p. 493), was found meaning in all three realist paintings with the depictions presented regarding worker indicators and heavy working conditions of workers. In particular, this issue has been covered with the direct worker narration in Courbet's The Stonebreakers, the agricultural society in Millet's The Gleaners, and the worker (proletariat) narratives in Menzel's The Iron Rolling Mill based on the characteristics of the newly industrialized society. Again, in the paintings, visual narratives for the industrialization, which is the subject of sociology, were encountered. While Menzel's The Iron Rolling Mill showed a clear narrative feature on the subject of the industrial revolution; Courbet's The Stonebreakers and Millet's The Gleaners depicted this issue through critical deep narrative messages within the framework of the concept of the labor force. It is seen that in the deep meaning layers of the vast majority of the visual indicators in the paintings are critical messages about social events and phenomena; therefore, the three realist paintings subject to the examination contain visual narratives with critical theory content. The fact that realist works of art are more 
closed to subjective interpretations than informal works has shown us the issue that the visual messages of these said works can be used as a kind of historical document and visual data in sociology and history research. 
